Ann. Génét. Sél. anim., I978, 10 (4), 569-578.

\title{
A genetic study of partial egg production records in a randombred Fayoumi flock
}

\author{
A. MOSTAGEER, Z. A. EZZELDIN, G. A. R. KAMAR and A. OBEIDAH \\ Animal Breeding Department, \\ Faculty of Agriculture, Cairo University \\ Giza (Egypt)
}

\section{Summary}

A genetic study of the annual egg production and 23 different partial records was done on 950 Fayoumi pullets, daughters of 40 sires and 3 I I dams, belonging to the Faculty of Agriculture Cairo University. The partial records include the egg production till 40,44, 48, 52 and 70 weeks of age using full trapnesting and partial trapnesting (3 days every week), together with the annual partial trapnesting record, beside the production during six fixed periods all in the first year of the bird's life (also using full and partial trapnesting).

Sire, dam and combined heritability estimates were computed for the 24 traits beside the genetic correlations between the annual full record and each of the 23 partial records.

Relative efficiencies of the genetic progress expected in the annual record using the different part records were studied. It was shown that the highest annual relative efficiency could be obtained by using for selection the production of the pullet during the 4 week period between 40 and 44 weeks of her age (trait Dr 2). A selection index using the production from first egg to the age of $4^{\circ}$ weeks (trait AI) beside trait Di 2 was shown to excel that of DI2.

\section{Introduction}

Partial recording, during specific periods or till fixed ages early in the production life of the fowl, beside reducing the generation interval, may help increase the annual progress when breeding for egg production. The partial trapnest records may also be effected by trapnesting only a few days every week to decrease further the amount of labour needed to evaluate the experimental birds. The significance of using partial records depends of course on the size of correlated response gained in the annual egg production record.

A considerable amount of work has been done on partial recording and trapnesting (e.g. : OlIVER et al., I957; WhEAT and LUSH, I96I; WARING et al., I962; Morris, I963; NoRDSkoG et al., I967; KINNEY et al., I968; BOHREN et al., I970, 
Sendhu and Dev, I972; Emsley, I973). Many of these studies showed that more genetic gain could be obtained in the full year egg production record when using partial records for the evaluation of animals. The objective of this work is to evaluate the necessary parameters of partial records in a randombred Fayoumi flock, in an attempt to seek the most economic method of recording that leads to the highest expected genetic gain in the annual egg production.

\section{Material and methods}

This work was carried out on the randombred Fayoumi flock belonging to the Faculty of Agriculture, Cairo University. The flock was not previously subjected to any kind of genetic selection. Fourty males and 400 females were randomly chosen and divided into 40 groups each of one male and ten females. Nine weekly hatches were obtained during the period from mid January to mid March, I974. The number of females actually contributing to the progeny used in this study was only $3 \mathbf{I}$. Individual daily egg production records were kept for each of 950 pullets of the progeny of these parents for a full year starting from sexual maturity. The following 24 traits were recorded for each individual (designations between brackets):

I. The total number of eggs laid till the ages of:

40 weeks (AI),
44 weeks (A2),
48 weeks (A3),
52 weeks (A4),
70 weeks (A5),

beside (A6); the complete annual egg production record (that is, the total number of eggs laid during a 365 day period from date of first egg).

2. The total number of eggs produced during the following periods of the first year of the bird's life:

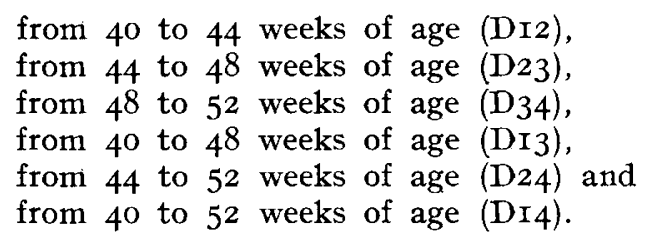

3. The number of eggs trapped in the first three consecutive days every week till the ages, or during the periods of the 12 traits described above. These traits will be given the same designations of the corresponding complete trapnesting traits using the lower case letters (thus, for instance, aI stands for the 3-days-aweek record of the number of eggs laid by the pullet till 40 weeks of her age).

Data were all corrected for hatch effect (which proved to be highly significant in all traits except DI2 and dI2) before performing the hierarchical analyses of variances and covariances. Sire, dam and combined heritabilities were estimated for all the traits beside the combined genetic correlations between $\mathrm{A} 6$ and 
the rest of the characters. The following table I shows the degrees of freedom and the $k$ values of the analyses. The standard errors of the heritability estimates were calculated according to the method suggested by Wool F (I96I), and those of the genetic correlations were estimated by RoBERTSON's (I959) formula.

TABLE I

Degrees of freedom and " $\mathbf{k}$ " values of the analyses

Degrés de liberté et valeurs " $\mathrm{k}$ » des analyses

\begin{tabular}{|c|c|c|c|c|c|}
\hline \multicolumn{3}{|c|}{ Degrees of Freedom between } & \multicolumn{3}{|c|}{$k$ values } \\
\hline Sires & $\begin{array}{c}\text { Dams / } \\
\text { Sires }\end{array}$ & $\begin{array}{c}\text { Progeny / } \\
\text { dams / } \\
\text { Sires }\end{array}$ & $k_{1}\left({ }^{1}\right)$ & $k_{2}\left({ }^{2}\right)$ & $k_{3}\left({ }^{3}\right)$ \\
\hline 39 & $27 \mathrm{I}$ & 639 & 2.968 & 3.628 & $23.5^{87}$ \\
\hline
\end{tabular}

(1) $k_{1}=$ The coefficient of the dam component in the MS or MCP between dams within sires.

(2) $k_{2}=$ The coefficient of the dam component in the MS or MCP between sires.

( $\left.{ }^{3}\right) k_{3}=$ The coefficient of the sire component in the MS or MCP between sires.

\section{Results and discussion}

\section{I. - The means}

The least squares means of the number of eggs laid by the fowl from first egg till the different ages used in this study are presented in table 2. The egg production of this Fayoumi base population is indeed low. As mentioned above, this flock has not been previously subjected to any kind of genetic selection. Starting from the age of 40 weeks it can be seen that the rate of egg production increased with the advancement of age till it reached its maximum during the period from $5^{2}$ to 70 weeks of age (when the rate was $39 \mathrm{p}$. I00). It may be mentioned that the least squares mean of age at sexual maturity was 38 weeks (266.I $4 \pm$ I.5 day), and thus the average age at which the bird completes its annual record may be taken as 90 weeks.

\section{II. - The heritabilities}

\section{Egg production till different ages :}

Sire, dam and combined heritability estimates $\left(h^{2}{ }_{s}, h^{2}{ }_{d}\right.$ and $h^{2}{ }_{c}$ resp.) of the number of eggs laid till the ages described above (the " $A$ " and " $a$ " traits) together with the amount of genetic and phenotypic variances are shown in table 3 . The 
TABLE 2

The least squares means ( \pm S.E.) of the number of eggs laid till certain ages of the bird's life

Moyennes obtenues par les moindres carrés, pour le nombre d'cufs pondus jusqu'à certains âges

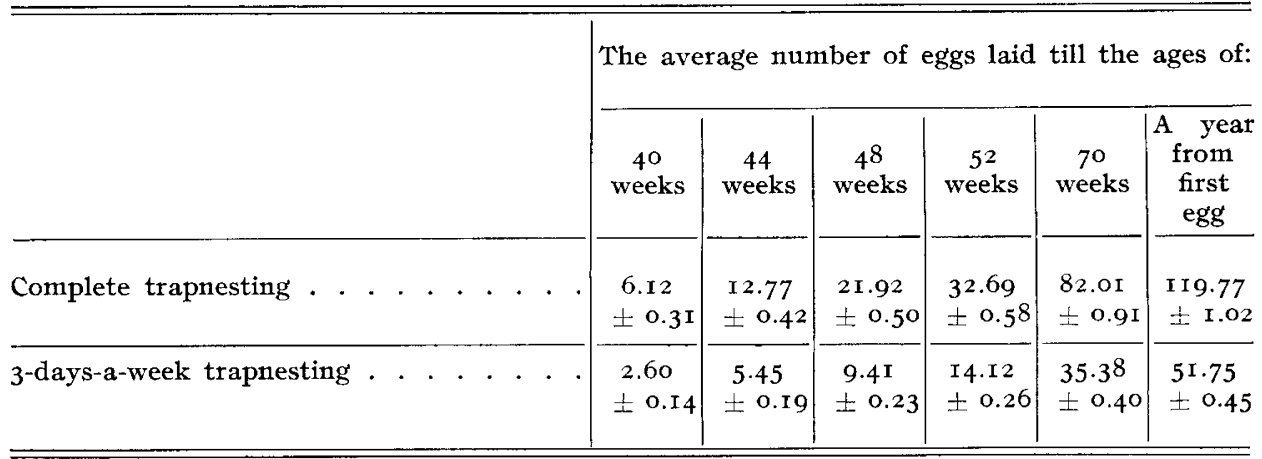

sire heritabilities of AI and $a$ I (egg production till 40 weeks of age) are a little bit higher than the dam heritabilities. This was not the case in the other " A " or " $a$ " traits in which the dam heritabilities were higher than the sire ones. The combined heritability estimates and the genetic variances increased in magnitude with the length of the recorded laying period till the age of 52 weeks. The combined heritability value of $A_{5}$ (the number of eggs laid till 70 weeks of age) is a little bit lower than that of $\mathrm{A}_{4}$. Table 3 shows that the amount of genetic variance of $\mathrm{A}_{5}$ is almost double that of $\mathrm{A}_{4}$ (I43.2 vs 74.5), and the lower heritability of $\mathrm{A}_{5}$ is due to the very high increase of the phenotypic variance. The same picture could be seen also with respect to $a_{4}$ and $a_{5}$. The combined heritability value of A6 (the complete annual record) is indeed low (o.og) and table 3 makes it clear that the amount of genetic variance of this character is almost the same as that of $\mathrm{A}_{4}$, and that the amount of phenotypic variance is about three times the corresponding amount of $\mathrm{A}_{4}$. Again an exact picture could be observed with respect to $a 6$ and $a_{4}$. The combined heritability of A6 is lower than most of the published comparable heritabilities (e.g., KING and HENDERSON, I954; AMER, I967; BOHREN et al., I970; ACHARYA et al., I97I). But the value of combined heritability of AI (egg production till 40 weeks of age) obtained in this study (0.I76) is very much the same as those obtained by WARING et al. (Ig62) (0.I9) and KINNEx and Lowe (Ig68) (o.I8). Also, the $h^{2}{ }_{c}$ estimate obtained in this work for A4 (egg production till 52 weeks of age) (0.267) is very close to the estimate of 0.29 for egg production till 55 weeks of age obtained by WARING et al. (I962). The value of 0.28 for combined heritability was reported by KINNEY and L,WE (I968) for the number of eggs laid till 72 weeks of age, and is not much different from the estimate of $\mathrm{A}_{5}$ (number of eggs laid till 70 weeks of age) obtained in this work (0.2I).

It might be of interest to note that the combined heritability values of the 3-days-a-week trapnesting records are all lower than the comparable values of the complete trapnesting records. All the " $a$ " traits have less genetic variance (except $a \mathrm{I}$ ) and more phenotypic variance compared to the corresponding " A " traits (that is; after multiplying the $\sigma_{g}^{2}$ and $\sigma^{2} p$ of the " $a$ " traits by 49/9). 
TABLE 3

Sive, dam and combined heritability estimates $\left( \pm\right.$ S.E.) and the genetic $\left(\sigma^{2} g\right)\left({ }^{1}\right)$ and phenotypic $\left(\sigma^{2} p\right)$ variances of the number of eggs laid till certain ages

Estimations paternelles, maternelles et combinées de l'héritabilité ( \pm écart-type) et variances génétiques $\left(\sigma_{g}^{2}\right)$ et phénotypiques $\left(\sigma^{2} p\right)$ du nombre d'aufs pondus jusqu'à certains âges

\section{I. - Full Trapnesting}

\begin{tabular}{|c|c|c|c|c|c|c|}
\hline \multicolumn{7}{|c|}{ Trait } \\
\hline & AI & $\mathrm{A}_{2}$ & $A_{3}$ & $\mathrm{~A}_{4}$ & $A_{5}$ & A6 \\
\hline$h^{2}$. . . . & $\begin{array}{c}0.179 \\
\pm 0.082\end{array}$ & $\begin{array}{l}0.163 \\
\pm 0.08 \mathrm{I}\end{array}$ & $\begin{array}{c}0.152 \\
\pm 0.082\end{array}$ & $\begin{array}{c}0.098 \\
\pm 0.073\end{array}$ & $\begin{array}{c}0.07 \mathrm{I} \\
\pm 0.065\end{array}$ & $\begin{array}{r}-0.035 \\
\pm 0.042\end{array}$ \\
\hline$h^{2} d . . \cdot$ & $\begin{array}{c}0.174 \\
\pm 0.143\end{array}$ & $\begin{array}{c}0.25 \mathrm{I} \\
\pm 0.148\end{array}$ & $\begin{array}{l}0.356 \\
\pm \quad 0.155\end{array}$ & $\begin{array}{c}0.436 \\
\pm 0.16 \mathrm{I}\end{array}$ & $\begin{array}{c}0.346 \\
\pm 0.157\end{array}$ & $\begin{array}{l}0.213 \\
\pm 0.153\end{array}$ \\
\hline$h_{c}^{2}$. . . . . & $\begin{array}{c}\text { o.1 } 76 \\
\pm 0.077\end{array}$ & $\begin{array}{c}0.207 \\
\pm 0.078\end{array}$ & $\begin{array}{l}0.254 \\
\pm 0.080\end{array}$ & $\begin{array}{c}0.267 \\
\pm 0.080\end{array}$ & $\begin{array}{c}0.208 \\
\pm 0.077\end{array}$ & $\begin{array}{l}0.089 \\
\pm 0.070\end{array}$ \\
\hline$\sigma^{2} g . . .$. & 14.05 & $30.8 \mathrm{I}$ & $5^{2.95}$ & 74.53 & I 43.16 & 76.39 \\
\hline$\sigma_{2 p} \cdot \cdot$ & 79.69 & $\mathbf{1 4} 8.77$ & 208.64 & $278.9 \mathrm{I}$ & $687.5^{\circ}$ & 855.97 \\
\hline
\end{tabular}

II. - 3-days-a-week 'Trapnesting

Trait

\begin{tabular}{|c|c|c|c|c|c|c|}
\hline & $a \mathrm{I}$ & $a 2$ & $a_{3}$ & $a_{4}$ & $a_{5}$ & $a 6$ \\
\hline$h_{s}^{2} . .$. & $\begin{array}{c}0.177 \\
\pm 0.082\end{array}$ & $\begin{array}{c}0.163 \\
\pm 0.080\end{array}$ & $\begin{array}{c}0.183 \\
\pm 0.085\end{array}$ & $\begin{array}{l}\text { o.I43 } \\
\pm 0.079\end{array}$ & $\begin{array}{c}0.113 \\
\pm 0.072\end{array}$ & $\begin{array}{c}0.005 \\
\pm 0.047\end{array}$ \\
\hline$h_{d}^{2} \cdot \ldots$ & $\begin{array}{c}\text { o.I59 } \\
\pm 0.142\end{array}$ & $\begin{array}{c}0.203 \\
\pm 0.145\end{array}$ & $\begin{array}{c}0.234 \\
\pm 0.147\end{array}$ & $\begin{array}{c}0.320 \\
\pm 0.152\end{array}$ & $\begin{array}{c}0.27^{2} \\
\pm 0.15 \mathrm{x}\end{array}$ & $\begin{array}{c}\text { o.1 } 50 \\
\pm 0.148\end{array}$ \\
\hline$h^{2}{ }_{c} \cdot$ & $\begin{array}{c}0.168 \\
\pm 0.076\end{array}$ & $\begin{array}{c}0.183 \\
\pm 0.077\end{array}$ & $\begin{array}{c}0.209 \\
\pm 0.078\end{array}$ & $\begin{array}{c}0.23 \mathbf{I} \\
\pm 0.079\end{array}$ & $\begin{array}{c}0.193 \\
\pm 0.076\end{array}$ & $\begin{array}{l}0.077 \\
\pm 0.069\end{array}$ \\
\hline . . . & 2,63 & $5 \cdot 35$ & 8.88 & 13.I5 & 25.84 & I 2.84 \\
\hline$\sigma_{p}^{2}$ & I5.6I & 29.27 & $4^{2.59}$ & 56.88 & I34.I9 & $166.3 \mathrm{I}$ \\
\hline
\end{tabular}

${ }^{(*)} \sigma^{2} g$ is taken as double the sum of the sire plus the dam components of variance.

\section{2. - Egg production of different periods of pullet's production life:}

Table 4 shows the sire, dam and combined heritability values together with the amount of genetic and phenotypic variances of the number of eggs laid during the different periods of the first year of the pullet's life (the " $D$ " and " $d$ " traits). It could be seen in all these traits that the dam heritabilities are higher than the 
TABLE 4

Sire, dam and combined heritability estimates $( \pm S . E$.$) and the genetic \left(\sigma^{2} g\right)$ and phenotypic $\left(\mathrm{o}^{2} p\right)$ variances of the number of eggs laid during certain periods of the laying year

Estimations paternelles, maternelles et combinées ( \pm écart-type) de l'héritabilité, et variances génétiques $\left(\sigma^{2} g\right)$ et phénotypiques $\left(\sigma^{2} p\right)$ du nombre d'cuts pondus durant certaines périodes de l'année de ponte

I. - Full Trapnesting

\begin{tabular}{|c|c|c|c|c|c|c|}
\hline \multicolumn{7}{|c|}{ Trait } \\
\hline & Di 2 & $\mathrm{D}_{23}$ & $\mathrm{D}_{34}$ & Di 3 & D24 & $\mathrm{Dr}_{4}$ \\
\hline$h^{2}{ }_{8}$ & $\begin{array}{c}0.102 \\
\pm 0.070\end{array}$ & $\begin{array}{c}0.022 \\
\pm 0.052\end{array}$ & $\begin{array}{l}-0.075 \\
\pm 0.033\end{array}$ & $\begin{array}{c}0.099 \\
\pm 0.072\end{array}$ & $\begin{array}{r}-0.024 \\
\pm 0.044\end{array}$ & $\begin{array}{c}0.044 \\
\pm 0.061\end{array}$ \\
\hline$h^{2}{ }_{d} \ldots \ldots$ & $\begin{array}{c}0.299 \\
\pm 0.153\end{array}$ & $\begin{array}{c}0.202 \\
\pm 0.15^{\circ}\end{array}$ & $\begin{array}{c}0.148 \\
\pm 0.15 \mathrm{I}\end{array}$ & $\begin{array}{c}0.380 \\
\pm \quad 0.15^{8}\end{array}$ & $\begin{array}{c}0.222 \\
\pm 0.153\end{array}$ & $\begin{array}{c}0.374 \\
\pm 0.160\end{array}$ \\
\hline$h_{c}^{2} . . .$. & $\begin{array}{c}0.200 \\
\pm 0.077\end{array}$ & $\begin{array}{c}0.112 \\
\pm 0.07 \mathrm{I}\end{array}$ & $\begin{array}{c}0.036 \\
\pm 0.067\end{array}$ & $\begin{array}{c}0.240 \\
\pm 0.078\end{array}$ & $\begin{array}{c}\text { 0.100 } \\
\pm 0.070\end{array}$ & $\begin{array}{c}0.209 \\
\pm 0.076\end{array}$ \\
\hline$\sigma^{2} g$ & 4.23 & 2.36 & 0.80 & I $4 \cdot 37$ & 6.36 & 24.05 \\
\hline$\sigma^{2} p$. & 21.16 & 21.03 & 21.92 & 59.97 & 63.93 & II 5.28 \\
\hline
\end{tabular}

II. - 3 days-a-week Trapnesting

\begin{tabular}{|c|c|c|c|c|c|c|}
\hline \multicolumn{7}{|c|}{ Trait } \\
\hline & $d_{12}$ & $d 23$ & $d_{34}$ & $d \mathbf{1 3}$ & $d 24$ & $d_{14}$ \\
\hline$h^{2}{ }_{s} \cdot \cdot \cdot$ & $\begin{array}{c}0.097 \\
\pm 0.067\end{array}$ & $\begin{array}{c}0.056 \\
\pm 0.057\end{array}$ & $\begin{array}{l}-0.055 \\
\pm 0.036\end{array}$ & $\begin{array}{c}0.129 \\
\pm \quad 0.075\end{array}$ & $\begin{array}{c}\text { o.0I6 } \\
\pm 0.049\end{array}$ & $\begin{array}{c}0.088 \\
\pm 0.067\end{array}$ \\
\hline$h^{2} d \cdot \cdot \cdot$ & $\begin{array}{c}0.199 \\
\pm 0.148\end{array}$ & $\begin{array}{c}0.146 \\
\pm 0.146\end{array}$ & $\begin{array}{c}\text { o.I40 } \\
\pm 0.149\end{array}$ & $\begin{array}{c}0.25^{2} \\
\pm 0.150\end{array}$ & $\begin{array}{c}\text { o.I } 32 \\
\pm \text { o.I46 }\end{array}$ & $\begin{array}{c}0.280 \\
\pm 0.153\end{array}$ \\
\hline$h_{c}^{2} . .$. & $\begin{aligned} & 0.148 \\
\pm & 0.074\end{aligned}$ & $\begin{array}{l}\text { o.roI } \\
\pm 0.07 \mathrm{I}\end{array}$ & $\begin{array}{c}0.042 \\
\pm 0.067\end{array}$ & $\begin{array}{c}0.190 \\
\pm 0.077\end{array}$ & $\begin{array}{c}0.074 \\
\pm 0.069\end{array}$ & $\begin{array}{c}0.184 \\
\pm 0.076\end{array}$ \\
\hline$\sigma^{2} g . .$. & 0.70 & 0.49 & 0.23 & 2.45 & I.04 & 4.55 \\
\hline$\sigma_{p}^{2} . .$. & 4.72 & 4.89 & $5 \cdot 35$ & I 3.14 & $\mathbf{1 3 . 9 7}$ & $24 \cdot 73$ \\
\hline
\end{tabular}

$\left.{ }^{*}\right) \sigma^{2} g$ is taken as double the sum of the sire plus the dam components of variance.

sire estimates, and that the heritability estimates of the " $\mathrm{D}$ " traits are higher than the corresponding estimates of the " $d$ " characters. The amounts of phenotypic variance of the number of eggs laid during the 4 week periods of Dr2, D23 and D 34 are almost the same, but the genetic variance of the first period is markedly higher than the other two periods $(4.2,2.4$ and 0.8 resp.). In the 8 week periods (Dr3 and $\mathrm{D} 24$ ) it could be seen that the amount of genetic variance of the number of 
eggs laid in the first period (DI3) is more than double that of the number laid in the second period (D24). The same holds true with respect to di3 and d24. It could also be observed that the records which include the egg production during the period from 40 to 44 weeks of age (DI2, DI3 and DI4) showed all the highest sire, dam and combined heritability estimates, compared to the other three part records D23, D34 and D24. The same holds true also with respect to the " $d$ " traits. The period of production that showed the lowest heritability values is that between 48 and 52 weeks of age.

\section{III. - Genetic correlations and index efficiencies}

\section{I. - Genetic correlations with the annual record:}

Table 5 shows the genetic correlations and genetic covariances between A6 and all the part records used in this study. The genetic correlation between A6 and $a 6$ is complete. Among the other 22 part records, D23 showed the highest

\section{TABIE 5}

Combined genetic correlations $\left(\mathbf{r}_{g}\right)\left( \pm\right.$ S.E.) and the genetic covariances $(\operatorname{cog})\left({ }^{*}\right)$ between the complete annual egg production record $(A 6)$ and the different part records

Corrélations génétiques combinées $\mathrm{r}_{g}$ (土écart-type) et covariances génétiques (cog) entre la ponte annuelle totale $(A 6)$ et les différentes mesures partielles

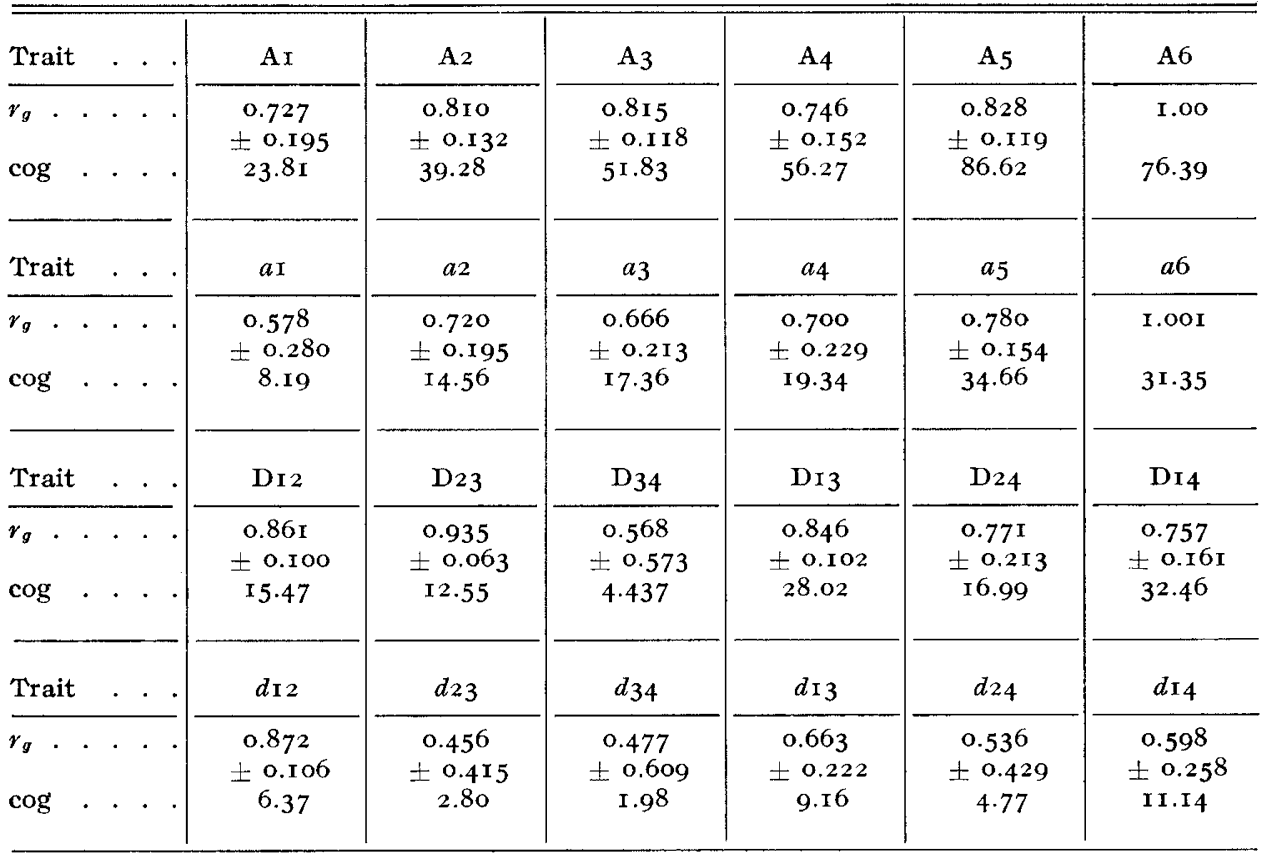

(*) $\operatorname{Cog}$ is taken as double the sum of the sire plus the dam components of covariance. 
correlation with A6 $\left(r_{g}=0.935\right)$, and the following characters showed genetic correlations of more than 0.8 (in descending order): $d$ I2 $_{2}, \mathrm{D}_{2} 2, \mathrm{D}_{1}, \mathrm{~A}_{5}, \mathrm{~A}_{3}$ and A2. The lowest $r_{g}$ values were those between $\mathrm{A} 6$ and $d 23, d 34$ and $d 24$; the partial trapnesting records collected during the first year of the bird's life, during the periods that do not include the production of the period from 40 to 44 weeks of age.

\section{2. - Relative efficiency of selection on part records in improving the annual egg production:}

The significance of using part records depends upon the expected correlated response gained in the annual record (A6) by selection on the part records(FALCONER, I $96 \mathrm{r})$. The amount of correlated response in the annual record is equal to $\left(i \sigma_{g} r_{g} h_{x}\right)$; where $i$ is the selection intensity, $\sigma_{g}$ is the genetic standard deviation of A6, $r_{g}$ is the genetic correlation between the A6 and the record $x$ and $h_{x}$ is the square root of the heritability of trait $x$. The response to direct selection on A6 will then be $i \sigma_{g} h_{\mathbf{A 6}}$. The ratio of the response obtained by indirect selection on trait $x$ to that gained by direct selection (that is; $r_{g} h_{x} / h_{\mathrm{A} 6}$ ) would show the relative efficiency (R. E.) per generation of the use of any part record in selection for $A 6$. The part records, usually completed early in the production life of the pullet, is supposed to decrease the generation interval, and the relative efficiency per year would then be the best yardstick for comparison. To compute the value of the relative efficiency per year, 8 weeks will be allowed. after the age at which the part

TABLE 6

Relative efficiency (R.E.) of selection on part records

Efficacité relative de la sélection sur enregistrements partiels

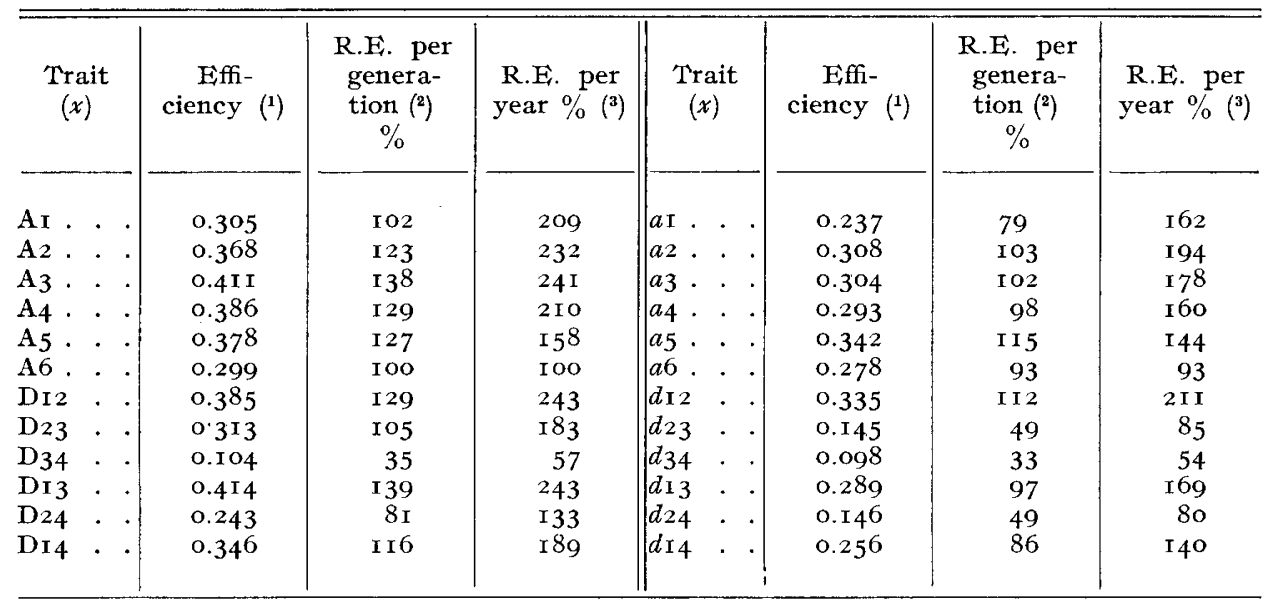

(1) Efficiency $=r_{g} h_{x}$; where $r_{g}$ is the genetic correlation between trait $x$ and $\mathrm{A} 6$.

(2) R. E. per generation $=$ (Efficiency of trait $x$ )/(Efficiency of trait A6).

$\left({ }^{3}\right)$ R. E. per year $=$ R. E. per generation multiplied by $98 / w_{x}$; where $w_{x}$ is equal to 8 plus the age (in weeks) when the partial record $x$ is completed. 
record is completed (for the collection and hatching of eggs to produce the new generation), bearing in mind that $\mathrm{A} 6$ is completed at an average age of 90 weeks. Table 6 shows the relative efficiency per generation and per year for the part records used in this study. $\mathrm{D}_{12}, \mathrm{D}_{1}, \mathrm{~A}_{3}$ and $\mathrm{A}_{2}$ give the highest expected yearly genetic gain in $\mathrm{A} 6$, followed by $\mathrm{d}_{\mathrm{I}}, \mathrm{A}_{4}$ and $\mathrm{AI}$. The first six of these seven part records involve the production of the 4 week period between 40 and 44 weeks of age. The egg production of this period, with complete or partial trapnesting (Dr2 and $d \mathrm{r} 2$ ) would be very convenient part records for the breeder since he can produce one generation every year ( 52 weeks). These two traits, DI2 and $d \mathbf{I} 2$, were also the only ones, among all the traits studied, which slowed no significant hatch effect.

Selection indexes involving two or more of the disussed part records could be used to attain higher efficiency. The following index is the one adopted now for selection in the Fayoumi flock of the Faculty of Agriculture, Cairo University. It involves the AI and DI2 traits; that is, the $A_{2}$ record divided in two pieces. The index equation to be solved was a follows:

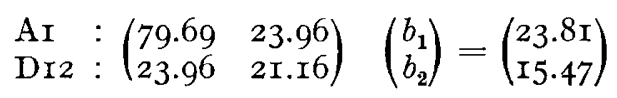

(23.96 = the phenotypic covariance between AI and DI2, other figures are shown in tables 3,4 and 5). The two regression coefficients are then

$$
b_{1}=0 . \operatorname{Irg} 6 \text { and } b_{2}=0.5957 \text {. }
$$

The accuracy (R) of the index (or the squared efficiency) is

$$
\mathrm{R}=\frac{(0 . \mathrm{IIg} 6 \times 23.8 \mathrm{I})+(0.5957 \times \mathrm{I} 5.47)}{76.39}=\frac{\mathrm{I} 2.065}{76.39}=0.1579
$$

where 76.39 is the genetic variance of A6. Thus the efficiency will be equal to 0.397 and the genetic standard deviation of the index will be 3.474 (the square root of 12.065). The relative selection efficiency of this index per generation is I34 p. I0o and per year is $25^{2} \mathrm{p}$. Ioo. If we select $20 \mathrm{p}$. Ioo of the pullets $(i=$ I.4) yearly using this index, the expected genetic superiority in A6 of the selected individuals will be:

$$
\Delta_{g}=\mathbf{I} .4 \times 3.474=4.86 \text { eggs, }
$$

or about 4.I p. Ioo of the mean of A6. Half of this superiority is expected to be recovered in the progeny every year.

Reçu pour publication en février 1979.

\section{Résumé}

\section{Étude génétique d'enregistrements partiels de la production d'ceufs dans un troupeau de Fayoumi en panmixie}

Une étude génétique de la production annuelle d'œufs et de 23 enregistrements partiels a été faite sur 950 poulettes Fayoumi, filles de 40 pères et de 3 I I mères, appartenant à la Faculté d'Agriculture, Université du Caire. Les enregistrements partiels comprennent la production d'œufs jusqu'à $40,44,48,52$ et 70 semaines d'âge avec trapnestage complet ou partiel (3 jours par semaine), la production annuelle estimée avec trapnestage partiel, enfin la production pen- 
dant six périodes fixées dans la première année de vie de la poule (également avec trapnestage complet ou partiel).

Des estimations d'héritabilité basées sur le père, la mère et combinées, ont été calculées pour les 24 caractères, ainsi que les corrélations génétiques entre la ponte totale annuelle et chacune des 23 mesures partielles.

Les efficacités relatives, exprimées d'après le gain génétique prévu dans la ponte annuelle en utilisant les différents enregistrements partiels, ont été examinées. Il est montré que l'efficacité relative la plus élevée serait obtenue en sélectionnant sur la production de la poulette pendant la période de 4 semaines comprise entre les âges de 40 et 44 semaines (caractère Di2). Un index de sélection, utilisant la production depuis le premier œuf jusqu'à l'âge de 40 semaines (caractère AI) et le caractère DI2, s'est révélé supérieur à Di 2 seul.

\section{References}

ACharya R. M., Dhilion J. S., Biswas D. K., I97I. Part vs. full-year record selection in breeding chickens for annual criterion egg production. Ind. J. Poult. Sci., 6, 7-II.

AMER M. F., r967. Heritability of egg production and egg weight in the Fayoumi. Poult. Sci., 46, 32-35.

Bohren B. B., KinNey T. B., Wilson S. P., Lowe P. C., r97o. Genetic gain in annual egg production from selection on part record percent in the fowl. Genetics, 65, 655-667.

EMSLEY J., 1973. Effect of heritability, genetic correlation and genotypic x environment interaction on expected response from selection for efficiency of strain-cross egg production in chickens. $\mathrm{Ph}$. D. Thesis, University of Nebraska.

FALCONER D. S., I96r. Introduction to quantitative Genetics. Oliver and Boyd, London.

KING S. C., HENDERSON C. R., 1954. Heritability estimates of egg production in the domestic fowl. Poult. Sci., 33, I55-I69.

KINNEY T. B., LOWE P. C., 1968. Genetic and phenotypic variation in the regional Red Controls over nine years. Poult. Sci., 47, Iro5-riro.

KINNEy T. B., LOWE P. C., BOHREN B. B., Wilson S. P., I968. Genetic and phenotypic variation in randombred White Leghorn Controls over several generations. Poult. Sci., 47, II3I23.

MORRIS J. A., 1963. Continuous selection for egg production using short-term records. Aust. J. Agric. Res., 14, 909-925.

NORDSKOG A. W., FESTrNG M., VerGHESE M. W., I967. Selection for egg production and correlated responses in the fowl. Genetics, 55, I79-I9I.

Olitver M. M., Bohren B. B., ANDerson V. L., I957. Heritability and selection efficiency of several measures of egg production. Poult. Sci., 36, 395-402.

ROBERTSON A., 1959. The sampling variance of the genetic correlation coefficient. Biometrics, 15, 469-485.

SANDhU J. S., DEV D. S., 1972. Efficiency of selection based on part year egg production. Ind. Poult. Gaz., 56, 83-9o.

Waring F. J., Hunton P., Maddison A. E., I962. Genetics of a closed poultry flock. I. Variance and covariance analysis of egg production, egg weight and egg mass. Brit. Poult. Sci., 3, I5I-I60.

WhEAT J. D., Lush J. L., I96r. Accuracy of partial trapnest records. Poult. Sci., 40, 399-406.

WOOLF B., 1961. Lectures in genetic statistics for the students of the Diploma in Animal Genetics. Edinburgh University. 